\title{
Determination of Arctic ice algal production with a new in situ incubation technique
}

\author{
Thomas Mock*, Rolf Gradinger \\ Sonderforschungsbereich 313 an der Universität Kiel, Heinrich-Hecht-Platz 10, D-24118 Kiel, Germany \\ and \\ Institut für Polarökologie, Wischhofstr. 1-3, Geb. 12, D-24148 Kiel, Germany
}

\begin{abstract}
A new in situ incubation technique was developed to measure primary production in sea ice. This method allows fine-scale measurements in $1 \mathrm{~cm}$ thick vertical sections throughout the ice column without severe disruption of ice morphology, geochemistry and light field. Easy handling in the field makes this device usable for all scientists working on sea ice biota. Primary production within first(FYSI) and multi-year sea-ice (MYSI) cores of the Barents and Greenland Seas was determined during the RV 'Polarstern' cruise ARK XIII/1(a+b). In order to measure algal production, 6 slices of $1 \mathrm{~cm}$ thickness were cut off at regular intervals along an ice core and incubated in sealed glass petri dishes. The incubation chambers and a chamber for dark fixation, together with the remaining sections of the ice core, were placed in an an acrylic-glass barrel of $1 \mathrm{~m}$ length, and returned to their original positions inside the core hole for in situ rate determinations. Additional ice cores were drilled to determine ice temperature and nutrient and algal pigment concentrations. The incident photosynthetically active radiation (PAR) as well as under ice irradiance was measured. Steep gradients in primary production. were found throughout the ice floes, with maximum values of $7.7 \mu \mathrm{g} \mathrm{C} \mathrm{I}^{-1} \mathrm{~h}^{-1}$ in the bottom few centimetres corresponding to the highest concentrations of chlorophyll a $\left(84 \mathrm{\mu g} \mathrm{l}^{-1}\right)$. Nutrient concentrations in brine varied between ice stations and with ice depth: $0-88.4 \mu \mathrm{mol} \mathrm{l}^{-1}$ for $\mathrm{NH}_{4} ; 2.2-13.6 \mu \mathrm{mol} \mathrm{l}^{-1}$ for $\mathrm{NO}_{3} ; 0-0.5 \mu \mathrm{mol} \mathrm{l} l^{-1}$ for $\mathrm{NO}_{2} ; 0-12.4 \mu \mathrm{mol} \mathrm{l}^{-1}$ for $\mathrm{PO}_{4}$; and $0.2-23.5 \mu \mathrm{mol} \mathrm{l} l^{-1}$ for $\mathrm{SiO}_{4}$. Mean integrated production at the 4 stations $\left(0.76-9.67 \mathrm{mg} \mathrm{C} \mathrm{m}^{-2} \mathrm{~d}^{-1}\right)$ varied with PAR and total dissolved nitrogen. Integrated production of the ice interior community (more than $5 \mathrm{~cm}$ from bottom of floe) was in the same range as or sometimes exceeded production in the bottom community $(0-5 \mathrm{~cm})$ of FYSI as well as MYSI. Growth rates of the ice algae ranged from 0.01 to $0.5 \mathrm{~d}^{-1}$. As previous primary production methods were restricted to the study of bottom communities only, we assert that algal primary production in Arctic as well as Antarctic sea ice has been severely underestimated.
\end{abstract}

KEY WORDS: Arctic - Sea ice - Algae - Biomass - Chlorophyll a In situ primary production - Growth rate Nutrients Methods

\section{INTRODUCTION}

Current estimates of primary production within sea ice have been calculated or modelled on the basis of sparse and incomplete data from both the Arctic and Antarctic, resulting in considerable discrepancies between studies (e.g. Legendre et al. 1992, Wheeler et al. 1996, Arrigo et al. 1997). Inherent spatial and temporal variability as well as methodological and logistic

\footnotetext{
- Present address: Alfred Wegener Institute for Polar and Marine Research, Am Handelshafen 12, D-27570 Bremerhaven, Germany. E-mail: tmock@awi-bremerhaven.de
}

constraints has prevented more reliable estimates. Erroneous assumptions about the extent and occurrence of algal communities within sea ice have aggravated this problem.

Dense biomass accumulations of Arctic sea-ice algae for instance have been mainly associated with (1) bottom communities (Horner 1985) and (2) sub-ice algal communities (Melnikov 1997). Yet recent studies on the vertical distribution of bacteria in pack ice floes from the Barents and Laptev Seas have revealed that the dominance of bottom communities in Arctic sea ice is not ubiquitous (Gradinger \& Zhang 1997). A similar study on the vertical fine structure of algal communities in Arctic 


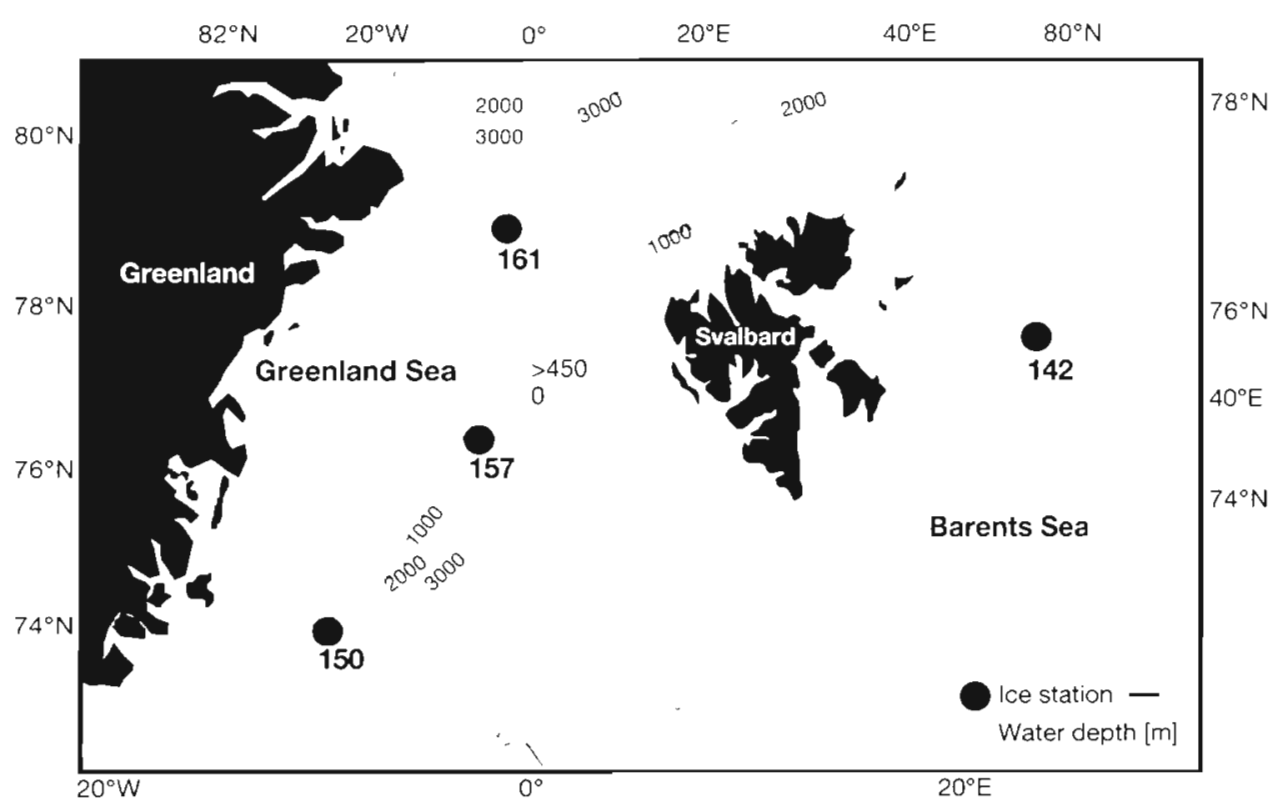

Fig. 1. Barents and Greenland Seas with location of sampling stations visited for this study during RV 'Polarstern' cruise ARK XIII/ $1(a+b)$ in May/June 1997 Station number: day of the year pack ice has shown that biomass maxima also occur within the ice interior (Gradinger 1999). These interior ice algal communities are common features in Antarctic sea ice (Meguro 1962, Burkholder \& Mandelli 1965). Interior ice algal communities have usually been disregarded in carbon production estimates for Arctic ice algae (e.g. Cota et al. 1991 and Gosselin et al. 1997). In past studies ice samples were usually obtained by diving and scraping off the ice underside (e.g. Palmisano et al. 1985, Syvertsen \& Kristiansen 1993) or by drilling ice cores either from the top or the bottom of the sea ice (e.g. McConville \& Wetherbee 1983, Rivkin et al. 1989). The samples were melted and incubated under simulated in situ conditions (e.g. Gosselin et al. 1986. Smith et al. 1988). Other more sophisticated techniques have enabled in situ under-ice incubations (Clasby et al. 1973. Schrader et al. 1982, Herman et al. 1993). Yet these methods all have limitations: in situ methods do not guarantee homogeneous tracer distribution within the samples and incubator techniques only simulate in situ conditions. Furthermore the ice is melted prior to determinations, leading to a destruction of the natural habitat. To overcome these constraints, we have developed a low cost, simple incubation technique. The technique facilitates the determination of vertical profiles of in situ ice algal production through the entire ice column, irrespective of ice thickness. It is based on ice coring, making diving operations or the use of remote-controlled devices obsolete. We tested the technique on first- and multi-year ice floes in the Barents and Greenland Seas, and we confirm the findings of Wheeler et al. (1996), who assume that current estimates of ice algal production in the Arctic are too low.

\section{MATERIAL AND METHODS}

Investigated area and sampling technique. This investigation was conducted on first-year sea-ice (FYSI) and multi-year sea-ice (MYSI) floes during the RV 'Polarstern' expedition ARK XIII/1 $(a+b)$ during May/June 1997 in the Barents and Greenland Seas. Sampling of ice cores as well as light and photosynthesis measurements was done at 4 stations (Fig 1). Three ice cores were drilled at each station: 1 for temperature measurements (Core 1), and nutrient and pigment concentrations and 2 for photosynthetic determinations (Cores 2 and 3). All ice cores were taken in proximity to each other, about $100 \mathrm{~m}$ away from the research vessel, using an ice corer ( $9 \mathrm{~cm}$ inner diameter). Care was taken to avoid disturbance of the site.

Irradiance measurements. Total photosynthetically active radiation (PAR) was measured with a $2 \pi$ sensor (LICOR 193) on the sea ice surface and a $4 \pi$ sensor (LICOR 193SB) directly at the underside of ice floes and recorded with a data logger (LICOR LI 1000) at stations 150, 157 and 161. After installation of the sensors, the core hole was covered with snow to the original snow depth. The $2 \pi$ sensor was placed approximately $10 \mathrm{~m}$ away from this hole. In order to calculate PAR for the ice layers in which we measured algal production, we used the light model of Smith et al. (1988) based on the under-ice $4 \pi$ PAR. The PAR flux on the top of each algal layer was calculated using the equation:

$$
E_{\mathrm{o}}=E_{\mathrm{u}} / \mathrm{e}^{\left.\mid-k_{i} \cdot Z_{1}-k_{\text {chi }} \cdot z_{\text {chi }}\right)}
$$

where $E_{0}=$ PAR on top of the algal layer $\left(\mu \mathrm{mol} \mathrm{m}^{-2} \mathrm{~s}^{-1}\right)$; $E_{\mathrm{u}}=\mathrm{PAR}$ penetrating through the algal layer $\left(\mu \mathrm{mol} \mathrm{m}^{-2}\right.$ 
$\left.\mathrm{s}^{-1}\right) ; k_{\mathrm{i}}=$ diffuse attenuation coefficient for ice $\left(1.5 \mathrm{~m}^{-1}\right)$ (Maykut 1985); $Z_{1}=$ ice thickness (m); $k_{\text {chl }}=$ mean spectral attenuation coefficient for chlorophyll a $\left(0.035 \mathrm{~m}^{2} \mathrm{mg}^{-1}\right)$ (Smith et al. 1988); $Z_{\text {chl }}=$ chlorophyll a $($ chl a) concentration in the algal layer $\left(\mathrm{mg} \mathrm{m}^{-2}\right)$.

Physico-chemical parameters and pigments. Snow depth was measured at each station prior to coring. Ice core temperature (Testotherm 700 thermometer) was recorded on Core 1 at 1 to $10 \mathrm{~cm}$ intervals immediately after extraction; the core was thereafter cut into 1 to $10 \mathrm{~cm}$ long sections using a stainless steel saw. Sections were transferred into clean polyethylene cans and transported to the ship. For nutrient and pigment concentrations, ice cores were melted at $4^{\circ} \mathrm{C}$ in the dark. Nutrient concentrations were determined according to the standard seawater procedures in Grasshoff et al. (1983). For the determination of algal pigment concentration (chl $a$ and phaeopigments), thawed core sections were filtered onto Whatman GF/F filters and analysed fluorometrically with a Turner Designs Model 10-AU digital fluorometer according to Arar \& Collins (1992). Brine salinity was calculated according to Assur (1958) and the nutrient concentrations were normalised to brine salinity (Gleitz et al. 1995).

Algal carbon production and growth rates. Core 2 was carefully extracted to avoid loss of the bottom portion. To minimise exposure of the shade-acclimated cells to the high irradiances above the ice, all ice core handling processes took place under dark foil. Using a stainless steel saw, 6 slices of $1 \mathrm{~cm}$ thickness were cut off at the following ice depths, beginning from the bottom of the core: (1) 0-1 cm, (2) $1-2 \mathrm{~cm}$, (3) $2-3 \mathrm{~cm}$, (4) $8-9 \mathrm{~cm}$, (5) $34-35 \mathrm{~cm}$ and (6) $60-61 \mathrm{~cm}$. Each of these 6 slices was put into a glass petri dish, inoculated with $15 \mathrm{ml}$ pre-filtered $(0.2 \mu \mathrm{m})$ sea water at in situ temperature and $50 \mu \mathrm{l}(15 \mu \mathrm{Ci}) \mathrm{NaH}^{14} \mathrm{CO}_{3}$ (Amersham International plc, Little Chalfont, UK). The petri dish was sealed with a small transparent non-toxic silicon ring and transparent thin tape. In order to determine the dark fixation, the bottom segment $(0-1 \mathrm{~cm})$ of Core 3 was treated like Core 2 but incubated in a black petri dish. The remaining core sections of the bottom $1 \mathrm{~m}$ of Core 2 together with the 6 petri dishes were placed in a transparent $1 \mathrm{~m}$ acrylic-glass barrel, in their original positions. This barrel was closed on the bottom with a water permeable lid (Fig. 2). Light measurements in the range 180 to $800 \mathrm{~nm}$ showed that the light transmission of the acrylic-glass was $>98 \%$ over the entire range. The black petri dish was placed below the ice

core in the same barrel. The barrel was then returned into the original core hole and secured with ropes. In ice floes thicker than $1 \mathrm{~m}$, the remaining upper portion of the ice core was also placed back into its original position above the incubation barrel. To minimise refreezing between the core segments and the core hole wall, this section was put into a thin and transparent plastic foil tube. Thereafter the core hole was covered with snow to the original snow depth

After 8 to 8.5 h incubation (see Table 1), the barrel was removed from the floe and immediately covered with black plastic foil and transported to the laboratory on RV 'Polarstern'. Each sample was preserved with $500 \mu \mathrm{l}$ DCMU [3-(3,4-dichlorophenyl)-1,1-dimethylurea, final concentration ca $2 \mathrm{mg} \mathrm{l}^{-1}$ ] after melting in the dark at room temperature. Three $15 \mathrm{ml}$ aliquots of each sample were acidified with $150 \mu 11 \mathrm{~N} \mathrm{HCl}(\mathrm{pH}<2)$. Non-fixed ${ }^{14} \mathrm{C}$ was removed by bubbling with air for $20 \mathrm{~min}$. Ten $\mathrm{ml}$ of each aliquot were dispensed into $20 \mathrm{ml}$ plastic vials and mixed with $10 \mathrm{ml}$ Lumagel scintillation cocktail (Baker). The samples were radio-assayed in a Packard TriCarb liquid scintillation counter. Quench correction was performed by automatic external standardisation. 
Table 1. Comparison of sampling stations based on ice type (FYSI: first-year sea ice; MYSI: multi-year sea ice), ice and snow thickness $(\mathrm{cm})$, under ice irradiance (\% of surface), incubation period ( $T_{\text {incubationi }}$ UTC), primary production $\left(\mathrm{mg} \mathrm{C} \mathrm{m}^{-2} \mathrm{~d}^{-1}\right), \mathrm{chl} \mathrm{a}^{-}$ specific photosynthetic rate $\left(P^{c h l}\right)$ ( $\mu \mathrm{g} C \mu \mathrm{g} \mathrm{chl} a^{-1} \mathrm{~h}^{-1}$ ), photosynthetic efficiency $\left(\alpha^{*}\right.$, defined in 'Material and methods') ( $\mu \mathrm{g} \mathrm{C} \mu \mathrm{g}$ chl $a^{-1} h^{-1}$ ) (umol photons $\left.\mathrm{m}^{-2} \mathrm{~s}^{-1}\right)^{-1}$, growth rate $(\mu+r)$, which is the sum of the specific growth rate and the specific rate of dark respiration $\left(\mathrm{d}^{-1}\right)$ and $\mathrm{chl}$ a $\left(\mathrm{mg} \mathrm{m}^{-2}\right]_{\text {i values represent means or ranges }}$

\begin{tabular}{|c|c|c|c|c|c|}
\hline & & $\operatorname{Stn} 142$ & Stn 150 & Stn 157 & $\operatorname{Stn} 161$ \\
\hline \multicolumn{2}{|l|}{ Ice type } & FYSI & FYSI & MYSI & MYSI \\
\hline \multicolumn{2}{|l|}{ Ice thickness } & 113 & 174 & 297 & 306 \\
\hline \multicolumn{2}{|c|}{ Snow thickness } & 7 & 40 & 46 & 66 \\
\hline \multicolumn{2}{|c|}{ Under-ice irradiance } & No data & 2.3 & 0.2 & 0.03 \\
\hline \multicolumn{2}{|c|}{$T_{\text {iñéubation }}$} & $08: 30-16: 30 \mathrm{~h}$ & $08: 45-17: 15 \mathrm{~h}$ & $08: 45-16: 45 \mathrm{~h}$ & $08: 30-16: 30 \mathrm{~h}$ \\
\hline \multirow{2}{*}{$\begin{array}{l}\text { Primary } \\
\text { production } \\
p^{c h l}\end{array}$} & $\begin{array}{l}\text { Interior }(>5-61 \mathrm{~cm}) \\
\text { Bottom }(0-5 \mathrm{~cm})\end{array}$ & $\begin{array}{l}7.11 \\
2.56\end{array}$ & $\begin{array}{l}1.71 \\
0.87\end{array}$ & $\begin{array}{l}0.25 \\
0.51\end{array}$ & $\begin{array}{l}1.23 \\
0.25\end{array}$ \\
\hline & $\begin{array}{l}\text { Interior }(>5-61 \mathrm{~cm}) \\
\text { Bottom }(0-5 \mathrm{~cm})\end{array}$ & $\begin{array}{l}0.05-0.90 \\
0.09-0.18\end{array}$ & $\begin{array}{l}0.16-0.40 \\
0.04-0.31\end{array}$ & $\begin{array}{l}0.01-0.02 \\
0.02-0.04\end{array}$ & $\begin{array}{l}0.02-0.13 \\
0.03-0.05\end{array}$ \\
\hline$\alpha^{\cdot}$ & $\begin{array}{l}\text { Interior }(>5-61 \mathrm{~cm}) \\
\text { Bottom }(0-5 \mathrm{~cm})\end{array}$ & $\begin{array}{l}\text { No data } \\
\text { No data }\end{array}$ & $\begin{array}{c}\leq 0.01 \\
<0.01-0.02\end{array}$ & $\begin{array}{c}<0.01 \\
0.02-0.03\end{array}$ & $\begin{array}{l}0.06-0.23 \\
0.09-0.15\end{array}$ \\
\hline Growth rate & $\begin{array}{l}\text { Interior }(>5-61 \mathrm{~cm}) \\
\text { Bottom }(0-5 \mathrm{~cm})\end{array}$ & $\begin{array}{l}0.01-0.50 \\
0.01-0.33\end{array}$ & $\begin{array}{l}0.17-0.20 \\
0.03-0.18\end{array}$ & $\begin{array}{l}0.02 \\
0.01\end{array}$ & $\begin{array}{l}0.02-0.04 \\
0.03-0.05\end{array}$ \\
\hline Chl a & $\begin{array}{l}\text { Interior }(>5-61 \mathrm{~cm}) \\
\text { Bottom }(0-5 \mathrm{~cm})\end{array}$ & $\begin{array}{l}1.05 \\
0.95\end{array}$ & $\begin{array}{l}0.26 \\
0.34\end{array}$ & $\begin{array}{l}0.51 \\
0.45\end{array}$ & $\begin{array}{l}0.74 \\
0.21\end{array}$ \\
\hline
\end{tabular}
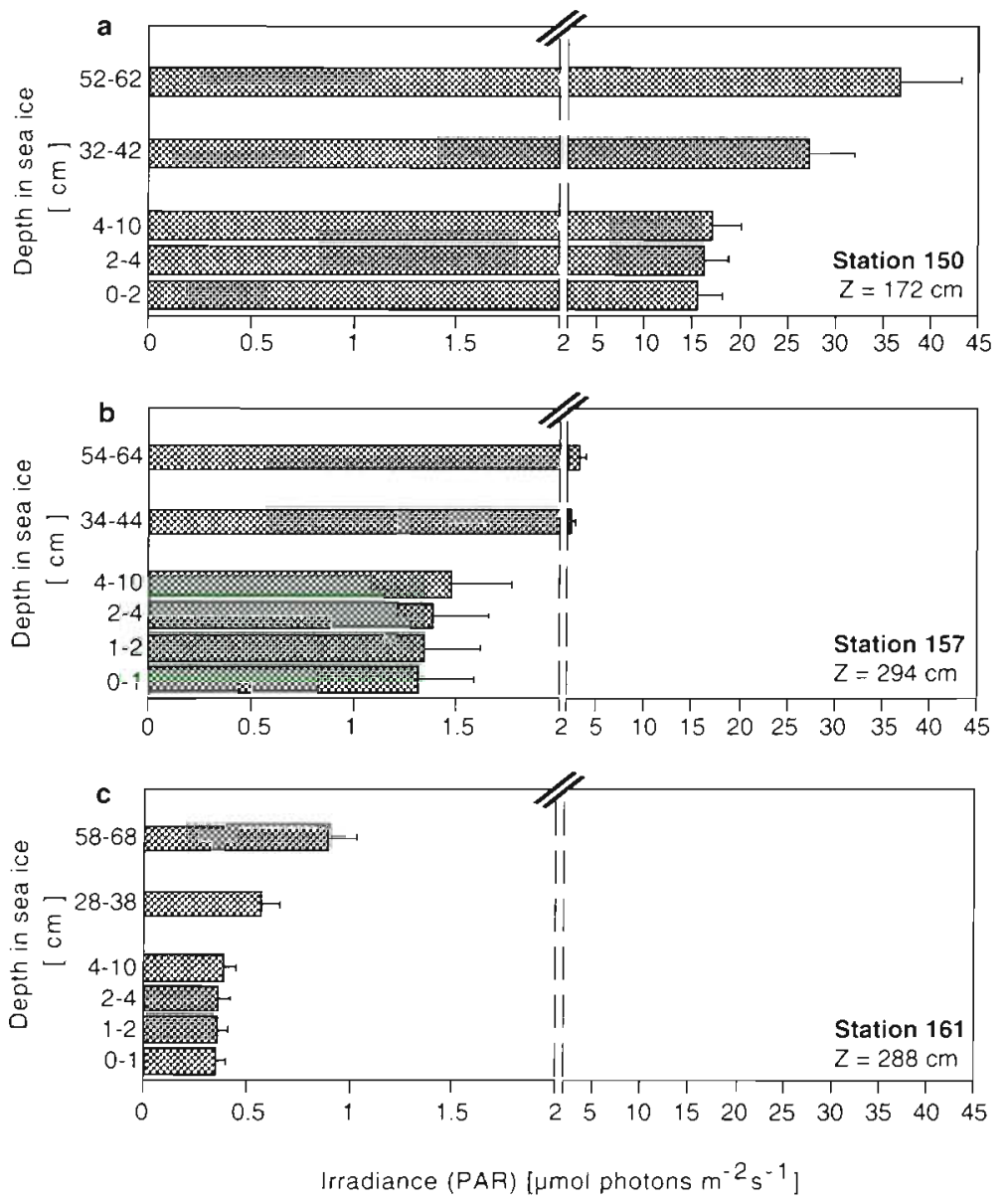

Fig. 3. Calculated irradiances (PAR) for the ice layers where primary production was determined. $\operatorname{Stn} 150 \mathrm{n}=480$, $\operatorname{Stn} 157 \mathrm{n}=482$, Stn $161 \mathrm{n}=482$; error bars denote standard deviations; $Z$ : ice thickness; depth intervals are given relative to the bottom of the ice floes
Carbon production rates were calculated according to Strickland \& Parsons (1972). The chl a-specific photosynthetic rate $p^{c h l}$ was calculated by dividing the primary production ( $\mu \mathrm{g} \mathrm{C}^{-1} \mathrm{~h}^{-1}$ ) with the chl a concentration ( $\mu \mathrm{g} c h l \mathrm{cl}^{-1}$ ). $\alpha^{*}$ is the ratio of $\mathrm{p}^{\mathrm{chl}} / \mathrm{PAR}$ ( $\mu \mathrm{g} \mathrm{C} \mu \mathrm{g} \mathrm{chl} \mathrm{a}^{-1} \mathrm{~h}^{-1}$ ) ( $\mu$ mol photons $\left.\mathrm{m}^{-2} \mathrm{~s}^{-1}\right)^{-1}$. Conventionally $\alpha$ is the initial slope of the $P$ (photosynthetic rate) versus $E$ (irradiance) curve and therefore not identical to $\alpha^{\circ}$. Gross algal growth rates $(\mu+r)$, which are the sum of the specific growth rate and the specific rate of dark respiration $\left(\mathrm{d}^{-1}\right)$, were estimated from the $P^{\mathrm{chl}}$ data (Sakshaug et al. 1989).

\section{RESULTS}

The absolute range of surface irradiance during the investigation was 106 to $2173 \mu \mathrm{mol} \mathrm{m} \mathrm{m}^{-2} \mathrm{~s}^{-1}$ Mean under-ice irradiance was below $2.3 \%$ of the incident surface irradiance. Unfortunately irradiance was not measured at Stn 142 (FYSI with $7 \mathrm{~cm}$ snow cover); however, $2.3 \%$ was measured under FYSI of Stn 150 with $40 \mathrm{~cm}$ of snow. Under MYSI, irradiances were lower, and only 0.2 (Stn 157) and $0.03 \%$ (Stn 161) of the incident surface irradiance were measured under the ice (Table 1). The calculated PAR values inside the ice floes decreased steeply with depth (Fig. 3) 

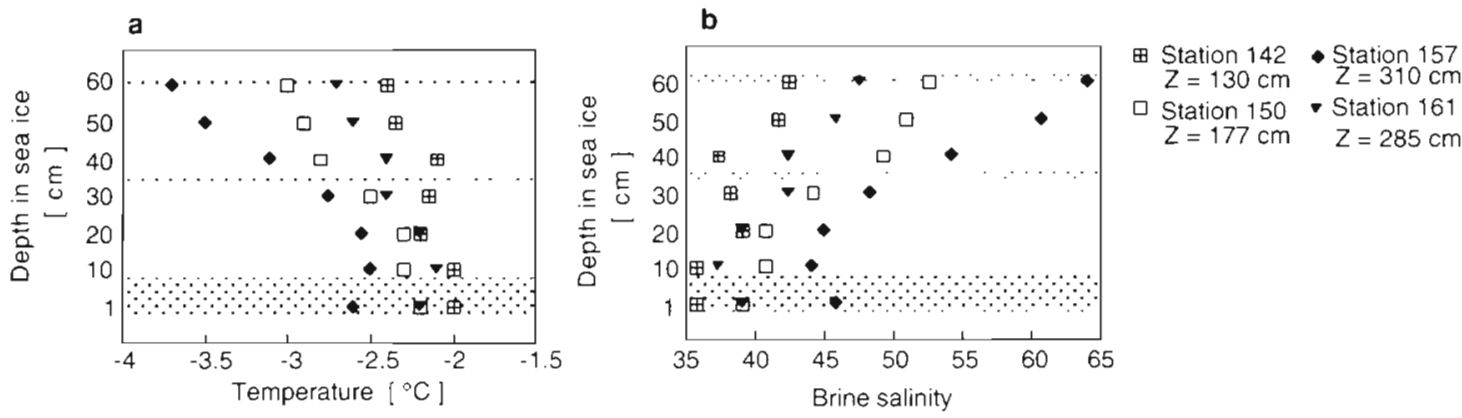

Fig. 4. Vertical profiles of (a) ice temperature and (b) brine salinity in the bottom $60 \mathrm{~cm}$ of the ice floes. Shaded areas represent layers where primary productivity was measured. Z: ice thickness; depth intervals are given relative to the bottom of the ice floes

The temperatures of FYSI and MYSI segments ranged between -2.0 and $-3.7^{\circ} \mathrm{C}$ and decreased with the distance from the ice-water interface (Fig. 4a). Calculated brine salinities ranged between 36 and 64 and increased with the distance from ice-water interface (Fig. $4 \mathrm{~b}$ ).

$\mathrm{NO}_{3}$ concentration in sea-ice brine varied between 2 and $14 \mu \mathrm{mol} \mathrm{l} \mathrm{l}^{-1}$, whereas $\mathrm{NH}_{4}$ concentration reached values between 0 and $88 \mathrm{mmol} \mathrm{l}^{-1}$ (Fig. 5). The vertical distribution of both nutrients was characterised by an increase towards the ice-water interface. A striking difference between FYSI and MYSI segments was the absence of $\mathrm{NH}_{4}$ in brine of MYSI, with 1 exception (88 $\mu_{\mathrm{mol} \mathrm{l}} \mathrm{l}^{-1} \mathrm{NH}_{4}$ at Stn 161). No corresponding differences existed for $\mathrm{SiO}_{4}, \mathrm{NO}_{2}$ and $\mathrm{PO}_{4}$. We found nearly no vertical gradients for these nutrients (Fig. 6), except at Stn 142, where concentrations increased towards the ice-water interface (Fig. 6a). The range of $\mathrm{SiO}_{4}$ was 0.2 to $23.5 \mu \mathrm{mol} \mathrm{l}{ }^{-1}$, that of $\mathrm{PO}_{4}$ was 0 to $12.4 \mu \mathrm{mol} \mathrm{l^{-1 }}$ and that of $\mathrm{NO}_{2}$ was 0 to $0.5 \mathrm{\mu mol} \mathrm{I}^{-1}$.

Chl a concentrations in FYSI and MYSI segments ranged between 0.2 and $84.4 \mu \mathrm{g} \mathrm{l}^{-1}$, with maximum concentrations in the bottom $2 \mathrm{~cm}$ (Fig. 7). Integrated $\mathrm{chl}$ a concentrations in the interior $(>5-61 \mathrm{~cm})$ ranged between 0.26 and $1.05 \mathrm{mg} \mathrm{m}^{-2}$, whereas the bottom layers $(0-5 \mathrm{~cm})$ contributed between 0.21 and $0.95 \mathrm{mg}$ chl $a \mathrm{~m}^{-2}$ (Table 1). The lowest phaeo:chl $\alpha$ ratios were found in the bottom $1 \mathrm{~cm}$ (Fig. 7) but no clear vertical trend was visible. The entire range of the phaeo:chl $a$ ratio was 0.03 to 0.71 .

The in situ primary production rate showed strong vertical variability, with maximum values of up to $7.7 \mu \mathrm{C} \mathrm{C} \mathrm{l}^{-1} \mathrm{~h}^{-1}$ (Fig. 8). The highest rates were always recorded within the bottom $1 \mathrm{~cm}$ and decreased rapidly with the distance from the ice-water interface, with the exception of Stn 142 which exhibited an internal production peak at $35 \mathrm{~cm}$ above the bottom (Fig. 8a). The highest integrated production rates were found in the interior ( $>5-61 \mathrm{~cm}$ ) of FYSI, with values of
$7.11 \mathrm{mg} \mathrm{C} \mathrm{m}{ }^{-2} \mathrm{~d}^{-1}$ at Stn 142 and $1.71 \mathrm{mg} \mathrm{C} \mathrm{m}^{-2} \mathrm{~d}^{-1}$ at Stn 150. These exceeded the rates in the bottom $5 \mathrm{~cm}$ at Stn 142 ca 3 -fold and at Stn 150 ca 2-fold (Table 1). The largest difference between interior and bottom portions was found in MYSI at Stn 161, with a ca 5-fold higher integrated primary production in the interior

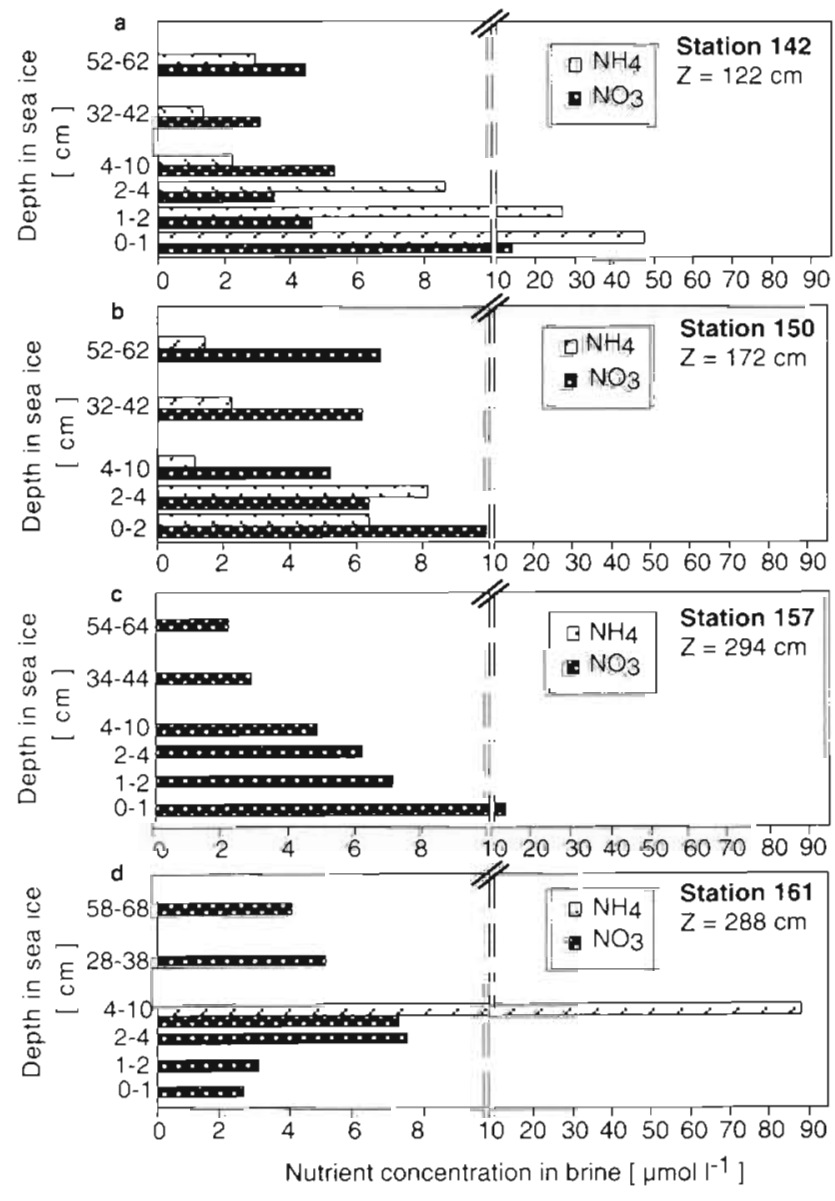

Fig. 5. $\mathrm{NO}_{3}$ and $\mathrm{NH}_{4}$ concentrations in brine in ice layers where primary production was determined. $Z$ : ice thickness: depth intervals are given relative to the bottom of the ice floes 


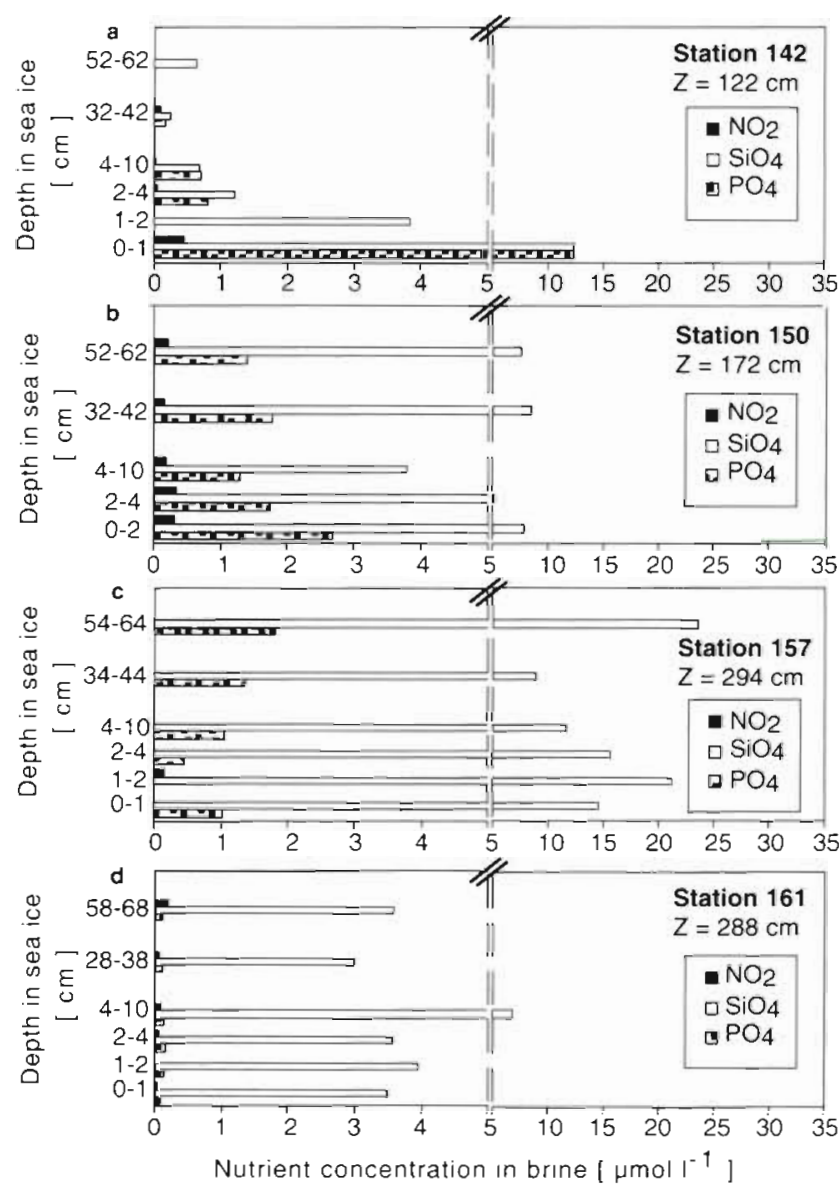

Fig. 6. $\mathrm{NO}_{2}, \mathrm{SiO}_{4}$ and $\mathrm{PO}_{4}$ concentrations in brine in ice layers where primary production was determined. $Z=$ ice thickness; depth intervals are given relative to the bottom of the ice floes

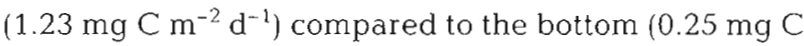
$\mathrm{m}^{-2} \mathrm{~d}^{-1}$ ) habitat. Only at Stn 157 did the rates in the bottom $\left(0.51 \mathrm{mg} \mathrm{C} \mathrm{m}^{-2} \mathrm{~d}^{-1}\right)$ exceed those of the interior $\left(0.25 \mathrm{mg} \mathrm{C} \mathrm{m}^{-2} \mathrm{~d}^{-1}\right)$. With the exception of Stn 157, the chl a-specific primary production ( $P^{\mathrm{chl}}$, Table 1) within the ice cores varied similarly to the already shown integrated primary production, with. highest values in the interior.

The photosynthetic efficiency, $\alpha$, showed no clear distinction between the bottom and interior parts of the ice floes. The highest values were determined in MYSI at Stn 161, with a maximum $\alpha^{*}$ of $0.23(\mu \mathrm{g} \mathrm{C} \mu \mathrm{g}$ chl $a^{-1} \mathrm{~h}^{-1}$ ) (umol $\left.\mathrm{m}^{-2} \mathrm{~s}^{-1}\right)^{-1}$ (Table 1), where light intensities were low due to a thick snow layer on the ice surface.

The range of growth rates was 0.01 to $0.5 \mathrm{~d}^{-1}$ (Table 1). Maximum values occurred in the interior parts of FYSI at Stn $142\left(0.5 \mathrm{~d}^{-1}\right)$ and Stn $150\left(0.2 \mathrm{~d}^{-1}\right)$. The algae in MYSI exhibited lower growth rates, between 0.01 and $0.05 \mathrm{~d}^{-1}$, with more or less identical rates in the interior and bottom parts (Table 1 ).

\section{DISCUSSION}

Photosynthetic rates of ice algae have been determined by a variety of in situ and artificial lightgradient incubation methods. Detailed comparisons between available methods of productivity determinations are provided by Horner (1990), Cota \& Smith (1991) and Herman et al. (1993). Compared to these, our new method has several advantages:

(1) It allows adequate tracer diffusion inside the sampled ice segment because of the short diffusion pathway through the $1 \mathrm{~cm}$ thick ice slices. In tests in daylight we observed that the tracer solution rapidly and completely penetrated into the interstitial ice crystal matrix. This is obviously not the case for other in situ techniques, which employ sub-ice incubator chambers (Clasby et al. 1973, Andersen 1977, Schrader et al. 1982, Booth 1984, Smith \& Herman 1991, 1992, Herman et al. 1993), the use of which consequently leads to an underestimate of production (Smith \& Herman 1991, 1992).

(2) Our method allows the determination of primary production profiles through the ice with high vertical resolution, and for the first time allows the determination of primary production over the entire ice thickness. This is of specific interest in sea ice with interior algal communities, such as in Antarctica (Spindler 1990, Palmisano \& Garrison 1993, Syvertsen \& Kristiansen 1993).

(3) Another advantage over determinations in the laboratory is the retained in situ temperature and light gradient within the ice after replacement of the incubation barrel. Determinations are done with nearly undisturbed ice morphology, geochemistry and light field.

(4) The experimental set up allows the determination of a wide range of physiological parameters (e.g. bacterial production or UV impact studies) by slight modifications of the tracer addition or transparency of the incubation barrel. The use of different material or foils (e.g. Villafane et al. 1995) enclosing the incubation barrel allows for in situ studies of e.g. UV-A and UV-B impacts on sea ice biota in general.

In autumn and winter, i.e. periods of low ice temperature and therefore high brine salinity, brine of adequate salinity should be used as the tracer solution instead of surface waters. It is well known from laboratory experiments that low temperature and light differences lead to large changes in photosynthetic parameters (Palmisano et al. 1987). Effects of photoinhibition after collecting the samples with a corer were avoided by doing all manipulations under dark plastic foil.

Certain disadvantages, however, arise both from the coring and during incubations. Small amounts of brine may leak out of the ice core while handling it, leading to an underestimate of primary production. Yet, in 

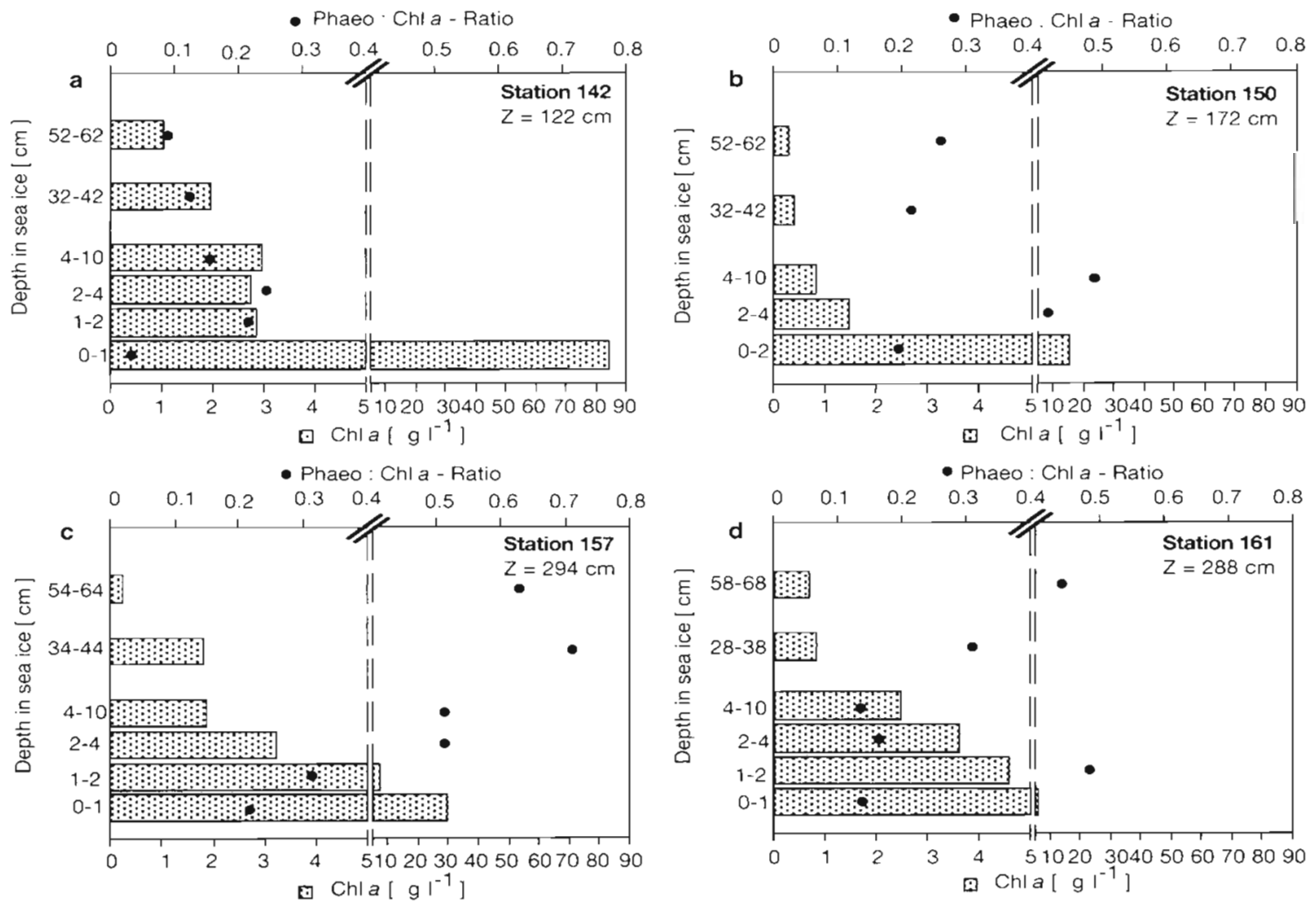

Fig. 7. Chl a distribution and phaeophytin:chl a ratios within ice segments where primary production was determined. $Z$ : ice thickness; depth intervals are given relative to the bottom of the ice floes

Antarctic sea ice, a large proportion of algal biomass (70 to $90 \%$ ) remains in ice sections after the brine has been collected by centrifugation (Weissenberger 1992). Since conditions in Arctic sea ice are similar, brine drainage would cause only a minor underestimate of primary production due to biomass loss but would on the other hand support tracer distribution within the ice matrix.

Incubation in jars isolates the ice biota from nutrient or DOC exchange with other parts of the sea ice or the water column. The significance of these processes, however, has been emphasised by several investigators (e.g. Cota et al. 1987, Bunch \& Harland 1990, Pomeroy et al. 1990, Gradinger et al. 1992, Thomas et al. 1995). Therefore we assume that our technique may underestimate primary production during periods with low nutrient concentrations.

The main abiotic parameters controlling algal growth rates are irradiance, nutrients, ice temperature and brine salinity (Gosselin et al. 1985, 1990, Maestrini et al. 1986, Cota et al. 1987, Grossi et al. 1987, Michel et al. 1988, Smith et al. 1988, Cota \& Sullivan 1990). The high photoacclimation potential of polar phytoplankton and sea-ice algal assemblages enables survival and rapid growth under low-light conditions (Rivkin \& Putt 1987, Cota \& Sullivan 1990, Gleitz \& Kirst 1991,
Johnsen \& Hegseth 1991). During our study ice temperatures in the incubated sections ranged between -2.0 and $-3.7^{\circ} \mathrm{C}$ (Fig. 4a). Although temperature has a strong overall impact on algal physiology, its effect on primary productivity is partially compensated for by a stronger decrease of respiration compared to algal assimilation (e.g. Tilzer \& Dubinsky 1987). Therefore we hypothesise that low ice temperatures in general did not retard algal production. In contrast irradiance and nutrient concentrations have strong impacts on algal biomass accumulation, biochemical composition and physiological status of the ice algae. Incident irradiance in polar areas varies primarily with season, over diel cycles and on even shorter time scales with cloud cover. Irradiances inside the ice are further modified by snow and ice thickness (Cota et al. 1991. Hegseth 1992).

$p^{c h l}$ ratios of the bottom communities within FYSI segments ranged between 0.04 and $0.31 \mu \mathrm{g} \mathrm{C} \mu \mathrm{g}$ chl $a^{-1} h^{-1}$ (Table 1). This is in good agreement with average responses of FYSI algae from bottom communities studied over 3 yr at a high Arctic site near Resolute Bay (Cota \& Smith 1991, Table 2). $P^{\text {chl }}$ ratios of the interior communities in FYSI segments ranged between 0.05 and $0.90 \mu \mathrm{g} \mathrm{C \mu g} \mathrm{chl} \mathrm{a}^{-1} \mathrm{~h}^{-1}$ (Table 1). $P^{\text {chl }}$ ratios of 0.02 to $0.05 \mu \mathrm{g} \mathrm{C \mu g} \mathrm{chl} \mathrm{a}^{-1} \mathrm{~h}^{-1}$ for bottom communities and 0.01 to $0.13 \mu \mathrm{g} \mathrm{C} \mu \mathrm{g}$ chl $a^{-1} \mathrm{~h}^{-1}$ for 


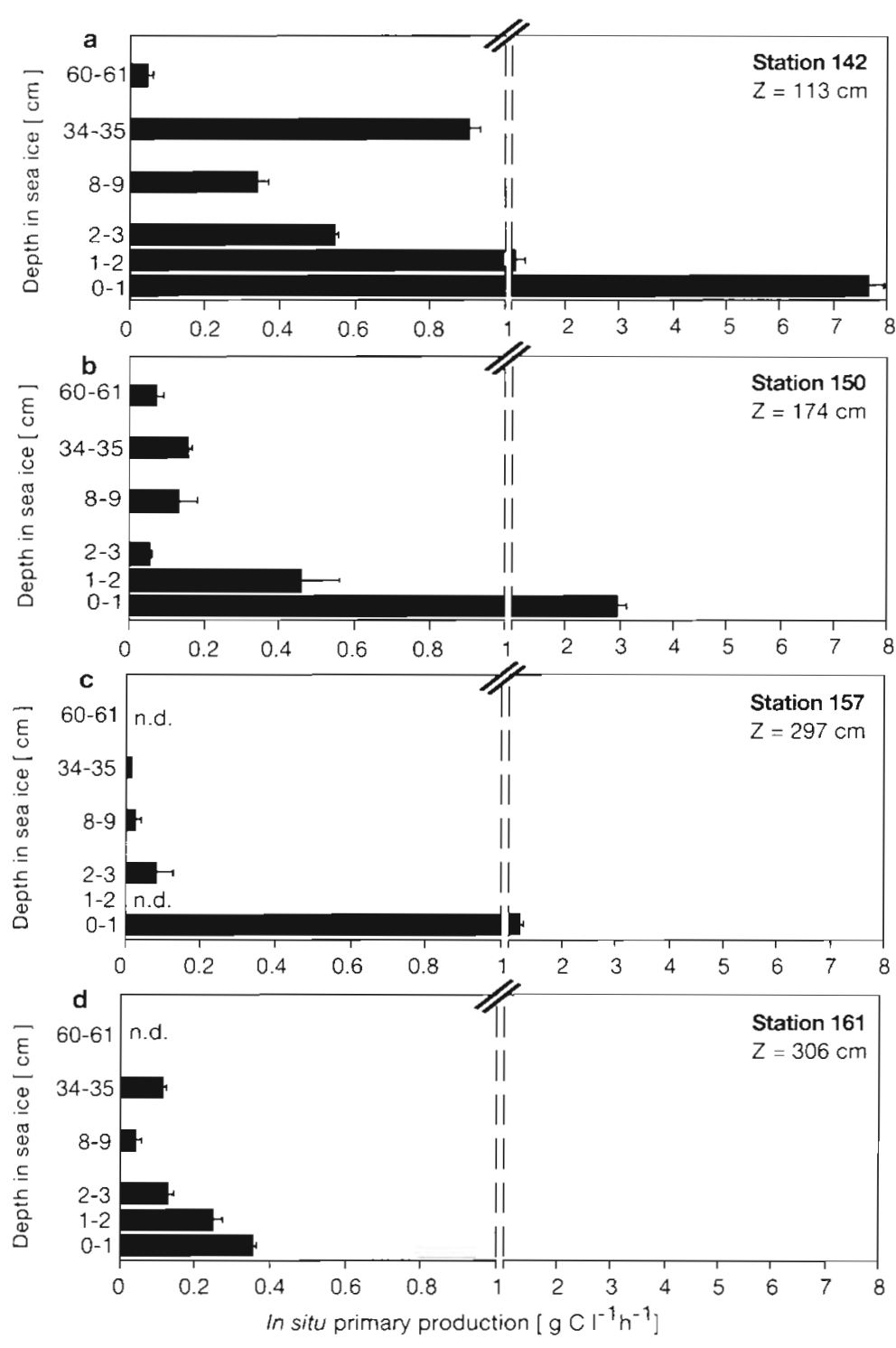

Fig. 8. Vertical profiles of in situ primary production. $\mathrm{n}=3$; error bars denote standard deviations; n.d.: no data; $Z$ : ice thickness; depth intervals are given relative to the bottom of the ice floes

1985, Smith et al. 1987), but coincide with laboratory values of 0.2 to $2 \mu \mathrm{mol}$ photons $\mathrm{m}^{-2} \mathrm{~s}^{-1}$ (Cota 1985, Horner 1985, Smith et al. 1985).

Photoacclimation to extremely low irradiance was also evident in $\alpha^{*}$, the photosynthetic efficiency, $\alpha^{*}$ within ice core segments increased with decreasing irradiance in MYSI to a maximum of 0.23 ( $\mu \mathrm{g}$ $\mathrm{C} \mu \mathrm{g} \mathrm{chl} \mathrm{a}^{-1} \mathrm{~h}^{-1}$ ) ( $\mu$ mol photons $\left.\mathrm{m}^{-2} \mathrm{~s}^{-1}\right)^{-1}$ at Stn 161, similar to observations from Antarctic ice algae (Palmisano et al. 1987). Thus, average values of $\alpha$ for ice algae are 2 to 3 times higher than those of phytoplankton (Cota \& Smith 1991). The total range of $\alpha^{*}$ in this study $(0.002-0.23)$ is comparable to that observed for other Arctic and Antarctic sea-ice algae (Kirst \& Wiencke 1995).

Highest production rates were found in the bottom centimetres on all ice floes (Fig. 8), despite low irradiances (Fig. 3). Two potential factors for this phenomenon are high nutrient availability and low brine salinity. Algal uptake will decrease nutrient concentrations inside the ice and within the interstices of the skeletal layer. Two mechanisms are known to replenish their nutrient demand: (1) molecular diffusion across the viscous sublayer, mainly in the skeletal layer, and (2) regeneration of nutrients, which is more important for internal communities (Cota \& Horne 1989, Dieckmann et al. 1991). The potential contribution of desalination of the ice sheet is predicted to be small (Cota et al. 1987). The observed steep gradients of dissolved $\mathrm{NO}_{3}$ and $\mathrm{NH}_{4}$ through the bottom few centimetres of the sea ice, especially at Stn 142, indicate a replenishment of these nutrients by hydrodynamic processes. The

interior communities of MYSI (Table 1) imply photosynthetic responses under very low light. Consequently light limitation of the ice algae was higher in MYSI than in FYSI. This is in correspondence with the low irradiances 10.36 to $3.3 \mu \mathrm{mol}$ photons $\mathrm{m}^{-2} \mathrm{~s}^{-1}$, Fig. 3) relative to saturation intensities around 5 to $10 \mu \mathrm{mol}$ photons $\mathrm{m}^{-2} \mathrm{~s}^{-1}$ (Cota 1985, Palmisano et al. 1985, 1987, Smith et al. 1987, 1988, Cota \& Sullivan 1990). We observed positive net photosynthesis at mean irradiance levels of $0.36 \pm 0.05 \mu \mathrm{mol}$ photons $\mathrm{m}^{-2}$ $\mathrm{s}^{-1}$ in the bottom centimetre at Stn 161. These irradiances are well below the threshold values from field observations ( 1 to $9.3 \mu \mathrm{mol}$ photons $\mathrm{m}^{-2} \mathrm{~s}^{-1}$; Alexander et al. 1974, Horner \& Schrader 1982, Gosselin et al. presence of ammonium within the ice as well as at the ice-water interface of FYSI suggests active regeneration by grazers and/or leaching from destroyed algae (Demers et al. 1989). All nutrient concentrations in brine were well above $k_{s}$ values (half saturation constant for nutrient uptake) of common microalgae (Sommer 1994). Therefore nutrient limitation can be excluded in this study, except for Stn 142, where very low silicate concentrations $\left(0.2\right.$ to $\left.0.7 \mu \mathrm{mol} \mathrm{SiO}_{4} \mathrm{l}^{-1}\right)$ in the brine might have caused growth limitation of diatoms $\left(k_{5}\right.$ for diatoms $=2$ to $5 \mu \mathrm{mol} \mathrm{l^{-1 }}$; Dieckmann et al. 1991, Sommer 1994). The overall correlation of primary production and therefore biomass accumulation with total dissolved nitrogen sources in our study was 
Table 2. Comparison of photosynthetic parameters and growth rates of bottom and interior ice algae: Photosynthetic efficiency

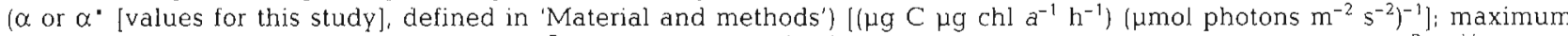
photosynthetic rate under light saturation $\left(P^{\mathrm{B}} \mathrm{m}\right)\left(\mu \mathrm{g} \mathrm{C} \mu \mathrm{g} \mathrm{chl} a^{-1} \mathrm{~h}^{-1}\right)$; biomass/chl a-specific photosynthetic rate $\left(P^{\mathrm{B}} / P^{\mathrm{ch}}\right.$ [ [values for this study) ( $\mu \mathrm{g} C \mu \mathrm{g}$ chl $\left.a^{-1} \mathrm{~h}^{-1}\right)$; integrated primary production (mg C m${ }^{-2} \mathrm{~d}^{-1}$ ); and growth rate $(\mu$ or $\mu+r)\left(\mathrm{d}^{-1}\right)$. Thicknesses of bottom and interior layers vary among studies; values represent means or ranges

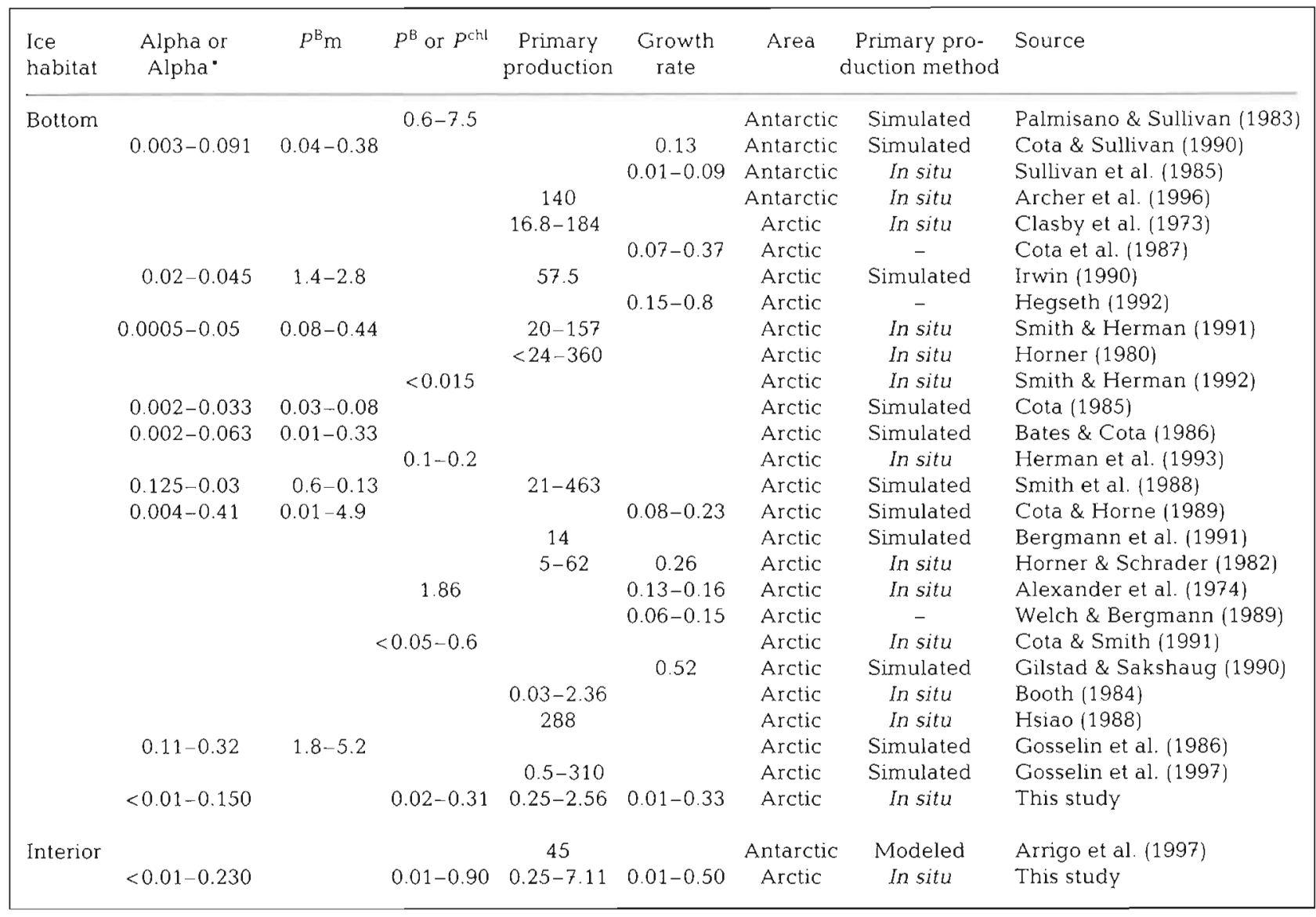

significant $\left(y=0.19+0.33 x_{i} r=0.5 ; n=21 ; p<0.05\right)$. No significant correlation could be found between primary production and the other dissolved nutrients ( $\mathrm{SiO}_{4}, \mathrm{NO}_{2}$ and $\mathrm{PO}_{4}$; data not shown).

The significance of brine salinity as a factor affecting physiological response of ice algae is well documented (e.g. Bunt 1968, Bates \& Cota 1986, Palmisano et al. 1987, Kottmeier \& Sullivan 1988, Fiala \& Oriol 1990, Kirst \& Wiencke 1995). Ice algae may be exposed to high salinities e.g. during brine drainage events (Grant \& Horner 1976) or when enclosed in brine pockets (Apollonio 1965, Meguro et al. 1966, 1967, Buinitsky 1977). Meguro et al. (1967) suggested that the drastic osmotic pressure change due to salinity was more important than low temperature or low nutrient concentration in limiting the survival of algae living in ice. Photosynthesis as well as photosynthetic capacity and efficiency decrease at high salinities (Bates \& Cota 1986), which may be a reflection of an inhibition of non-cyclic electron flow at PS II (Gilmour et al. 1984).
Thus, increasing salinities in the ice interior (Fig. 4b) partially explain decreasing production rates in these parts of the ice floes (Fig. 8). The lowest values for $\alpha^{*}$ and $P^{\mathrm{chl}}$ were found at Stn 157 (Table 1), which had low irradiance (Fig. 3) and also the highest salinities (Fig. 4b) and therefore both suppressive factors.

Ice algal growth rates are generally low because of low temperature and irradiance in the ice (Eppley 1972, Sullivan et al. 1985, Gilstad \& Sakshaug 1990). Average growth rates in FYSI were 1 order of magnitude higher than in MYSI. These rates are in agreement with data provided by Horner \& Schrader (1982) and Sullivan et al. (1985) for Arctic and Antarctic ice algae (Table 2). The higher growth rates of algae in FYSI were the consequence of stronger irradiance and higher concentrations of dissolved nitrogen. The occurrence of $\mathrm{NH}_{4}$ indicated that the algal bloom in FYSI was in a later state of development than in MYSI and regeneration processes were occurring, especially in the sea ice of the Barents Sea (Stn 142). 


\section{CONCLUSIONS}

A new method for in situ determination of primary production was developed in order to determine production rates representative of ice floes in general and comparable to those applied in plankton productivity studies. Low costs and easy handling of the device make it affordable and appropriate for all scientists working with sea ice biota.

Our data show that production rates and physiological acclimation of the bottom ice algal community are not characteristic of the entire ice community and represent only a fraction of the total primary production. $P^{\mathrm{chl}}$ of interior ice portions was higher because of the higher irradiance there; however, increasing salinity and decreasing nutrient concentrations and space availability reduce primary production in the interior of Arctic sea ice. Nonetheless, integrated production of the interior community was in the same range as or even exceeded production of the bottom community in FYSI as well as in MYSI. Previous simulated and in situ primary production methods have been restricted to the study of bottom communities only. Based on their spatial limitation and the inadequate tracer diffusion of in situ methods we assert that ice primary production has been underestimated. Such underestimates are also likely to be evident for Antarctic sea ice, where productivity studies of the frequently occurring biomass-rich infiltration and freeboard layers have been neglected (e.g. Arrigo et al. 1997).

Acknowledgements. We are grateful to the crew of the RV 'Polarstern' for their assistance during the expedition. We thank our colleagues B. Bluhm, G. Donner, F. Haass, K. Meiners, I. Werner and $Q$. Zhang and the numerous people who helped us during the field work. M. Krumbholz and I. Werner kindly assisted us with the POC samples, A. Lunau determined the nutrient concentrations. This study was generously supported by the Sonderforschungsbereich 313 and is SFB publication no. 347

\section{LITERATURE CITED}

Alexander V, Horner R, Clasby RC (1974) Metabolism of Arctic sea ice organisms. Report R74-4, Institute of Marine Science, University of Alaska, Fairbanks, p 1-120

Andersen OGN (1977) Primary production associated with sea ice at Godhaven Disko, Greenland. Ophelia 16:205-220

Apollonio S (1965) Chlorophyll in Arctic sea ice. Arctic 18: $118-122$

Arar EJ, Collins GB (1992) In vitro determination of chlorophyll $a$ and phaeophytin a in marine and freshwater phytoplankton by fluorescence. Method 445.0. In: US EPA. (ed) Methods for the determination of chemical substances in marine and estuarine environmental samples. US Environmental Protection Agency. Cincinnati, $\mathrm{OH}, \mathrm{p}$ 1-15

Archer SD, Leakey RJG, Burkill PH, Sleigh MA, Appleby CJ (1996) . .icrobial ecology of sea ice at a coastal. Antarctic site: community composition, biomass and temporal change. Mar Ecol Progr Ser 135:179-195

Arrigo KR, Worthen DL, Lizotte MP, Dixon P, Dieckmann G (1997) Primary production in Antarctic sea ice. Science 276:394-397

Assur A (1958) Composition of sea ice and its tensile strength In: National Academy of Sciences (ed) Arctic sea ice. Publ 598, National Research Council, Washington, DC, p $106-138$

Bates SS, Cota GF (1986) Fluorescence induction and photosynthetic response of Arctic ice algae to sample treatment and salinity. J Phycol 22:421-429

Bergmann MA, Welch HE, Butler-Walker JE, Siferd TD (1991) Ice algal photosynthesis at Resolute and Saqvaqjuac in the Canadian Arctic. J Mar Syst 2:43-52

Booth JA (1984) The epontic algal community of the ice edge zone and its significance to the Davis Strait ecosystem. Arctic 37:234-243

Buinitsky VK (1977) Organic life in sea ice. In: Dunbar MJ (ed) Polar oceans. Arc Inst N Amer, Calgary, p 301-306

Bunch JN, Harland RC (1990) Bacterial production in the bottom surface of sea ice in the Canadian Subarctic. Can J Fish Aquat Sci 47:1986-1995

Bunt JS (1968) Some characteristics of microalgae isolated from Antarctic sea ice. Antarct Res Ser 11:1-14

Burkholder PR, Mandelli EF (1965) Productivity of microalgae in Antarctic sea ice. Science 148:872-874

Clasby RC, Horner R, Alexander V (1973) An in situ method for measuring primary production of Arctic sea ice algae. J Fish Res Board Can 30:635-638

Cota GF, Smith REH (1991) Ecology of bottom ice algae: III. Comparative physiology. J Mar Syst 2:297-315

Cota GF, Sullivan CW (1990) Photoadaptation, growth and production of bottom ice algae in the Antarctic. J Phycol 26:399-411

Cota GF, Prinsenberg SJ, Bennett EB, Loder JW, Lewis MR, Anning JL, Watson NHF (1987) Nutrient fluxes during extended blooms of Arctic ice algae. J Geophys Res $92(C 2): 1951-1962$

Cota GF, Legendre L, Gosselin M, Ingram RG (1991) Ecology of bottom ice algae. I. Environmental controls and variability. J Mar Syst 2:257-277

Cota GF (1985) Photoadaptation of high Arctic ice algae Nature 315:219-222

Cota GF, Horne EPW (1989) Physical control of Arctic ice algal production. Mar Ecol Prog Ser 52:111-121

Demers S, Legendre L, Maestrini SY, Rochet M, Ingram RG (1989) Nitrogenous nutrition of sea-ice microalgae. Polar Biol 9:377-383

Dieckmann G, Lange M, Ackley SF, Jennings J Jr (1991) The nutrient status in sea ice of the Weddell Sea during winter: effects of sea ice texture and algae. Polar Biol 11:449-456

Eppley RW (1972) Temperature and phytoplankton growth in the sea. Fish Bull 70:1063-1085

Fiala M, Oriol L (1990) Light-temperature interactions on the growth of Antarctic diatoms. Polar Biol 10:629-636

Gilmour DJ, Hipkins MF, Boney AD (1984) The effect of decreasing the external salinity on the primary processes of photosynthesis in Dunaliella tertiolecta. J Exp Bot 35: $28-35$

Gilstad M, Sakshaug E (1990) Growth rates of ten diatom species from the Barents Sea at different irradiances and day lengths. Mar Ecol Prog Ser 64:169-173

Gleitz M. Kirst GO (1991) Photosynthesis-irradiance relationship and carbon metabolism of different ice algal assemblages collected from Weddell Sea pack ice during austral spring (EPOS 1). Polar Biol 11:385-392 
Gleitz M, Rutgers vd Loeff $M$, Thomas DN, Dieckmann GS, Millero FJ (1995) Comparison of summer and winter inorganic carbon, oxygen and nutrient concentrations in Antarctic sea ice brine. Mar Chem 51:81-91

Gosselin $M$, Legendre $L$, Demers $S$, Ingram RG (1985) Responses of sea ice microalgae to climatic and fortnightly tidal energy inputs (Manitounuk Sound, Hudson Bay). Can J Fish Aquat Sci 42:999-1006

Gosselin M, Legendre L, Therriault JC, Demers S, Rochet M (1986) Physical control of the horizontal patchiness of seaice microalgae. Mar Ecol Prog Ser 29:289-298

Gosselin M, Legendre L, Therriault JC, Demers S (1990) Light and nutrient limitation of sea ice microalgae. J Phycol 26: $220-232$

Gosselin M, Levasseur M, Wheeler PA, Horner RA, Booth BC (1997) New measurements of phytoplankton and ice algal production in the Arctic Ocean. Deep-Sea Res 44: $1623-1644$

Gradinger R (1999) Vertical fine structure of the biomass and composition of algal communities in Arctic pack ice. Mar Biol (in press)

Gradinger R, Zhang Q (1997) Vertical distribution of bacteria in Arctic sea ice from the Barents and Laptev Seas. Polar Biol 17:448-454

Gradinger R, Spindler M, Weissenberger J (1992) On the structure and development of Arctic pack ice communities in Fram Strait: a multivariate approach. Polar Biol 12:727-733

Grant WS, Horner RA (1976) Growth responses to salinity variation in four Arctic ice diatoms. J Phycol 12:180-185

Grasshoff K, Ehrhardt M, Kremling K (1983) Methods of seawater analyses. Verlag Chemie, Weinheim

Grossi SMCG, Kottmeier ST, Moe RL, Taylor GT, Sullivan CW (1987) Sea ice microbial communities. VI. Growth and primary production in bottom ice under graded snow cover. Mar Ecol Prog Ser 35:153-164

Hegseth EN (1992) Sub-ice algal assemblages of the Barents Sea: Species composition, chemical composition, and growth rates. Polar Biol 12:485-496

Herman AW, Knox DF, Conrad J, Mitchell MR (1993) Instruments for measuring subice algal profiles and productivity in situ. Can J Fish Aquat Sci 50:359-369

Horner R (1980) Ecology and productivity of Arctic sea ice diatoms. In: Ross R (ed) Proc. 6th Symp Recent Fossil Diatoms. Koeltz, Königstein, p 359-369

Horner R (ed) (1985) Sea ice biota. CRC, Boca Raton, FL

Horner R (1990) Techniques for sampling sea ice algae. In: Medlin LK, Priddle J (eds) Polar marine diatoms. British Antarctic Survey, Natural Environment Research Council, Cambridge, p 19-24

Horner R, Schrader GC (1982) Relative contribution of ice algae, phytoplankton, and benthic microalgae to primary production in nearshore regions of the Beaufort Sea. Arctic 35:485-503

Hsiao SIC (1988) Spatial and seasonal variations in primary production of sea ice microalgae and phytoplankton in Frobisher Bay, Arctic Canada. Mar Ecol Prog Ser 44:275-285

Irwin BD (1990) Primary production of ice algae on a seasonally-ice-covered, continental shelf. Polar Biol 10: $247-254$

Johnsen G, Hegseth EN (1991) Photoadaptation of sea ice microalgae in the Barents Sea. Polar Biol 11:179-184

Kirst GO, Wiencke C (1995) Ecophysiology of polar algae. J Phycol 31:181-199

Kottmeier ST, Sullivan CW (1988) Sea ice microbial communities (SIMCO). 9. Effects of temperature and salinity on rates of metabolism and growth of autotrophs and heterotrophs. Polar Biol 8:293-304
Legendre L, Ackley SF, Dieckmann GS, Gulliksen B, Horner R, Hoshiai T, Melnikov IA, Reeburgh WS, Spindler M, Sullivan CW (1992) Ecology of sea ice biota. 2. Global significance. Polar Biol 12:429-444

Maestrini SY, Rochet M, Legendre L, Demers S (1986) Nutrient limitation of the bottom-ice microalgae biomass (southern Hudson Bay, Canadian Arctic). Limnol Oceanogr 31:969-982

Maykut GA (1985) The ice environment. In: Horner R (ed) Sea ice biota. CRC Press, Boca Raton, p 21-82

McConville MJ, Wetherbee R (1983) The bottom-ice microalgal community from annual ice in the inshore waters of east Antarctica. J Phycol 19:431-439

Meguro H (1962) Plankton ice in the Antarctic Ocean. Antarct Rec 14:1192-1199

Meguro H, Ito K, Fukushima H (1966) Diatoms and the ecological conditions of their growth in sea ice in the Arctic Ocean. Science 152:1089-1090

Meguro H, Ito K, Fukushima H (1967) Ice flora (bottom type): a mechanism of primary production in polar seas and the growth of diatoms in sea ice. Arctic 20:114-133

Melnikov IA (1997) The Arctic sea ice ecosystem. Gordon and Breach Science Publishers, Amsterdam

Michel CL, Legendre L, Demers S, Therriault JC (1988) Photoadaptation of sea ice microalgae in springtime: photosynthesis and carboxylating enzymes. Mar Ecol Prog Ser 50:177-185

Palmisano AC, Garrison DL (1993) Microorganisms in Antarctic sea ice. In: Friedmann EI (ed) Antarctic microbiology. Wiley, New York, p 167-218

Palmisano AC, Sullivan CW (1983) Sea ice microbial communities (SIMCO) 1 Distribution, abundance, and primary production of ice microalgae in McMurdo Sound, Antarctica. Polar Biol 2:171-177

Palmisano AC, Kottmeier ST, Moe RL, Sullivan CW (1985) Sea ice microbial communities. IV: The effect of light perturbation on microalgae at the ice-seawater interface in McMurdo Sound, Antarctica. Mar Ecol Prog Ser 21:37-45

Palmisano AC, Beeler SooHoo J, Sullivan CW (1987) Effects of four environmental variables on photosynthesis-irradiance relationships in Antarctic sea-ice microalgae. Mar Biol 94:299-306

Pomeroy LR, Macko SA, Ostrom PH, Dunphy J (1990) The microbial food web in Arctic sea water: concentration of dissolved free amino acids and bacterial abundance and activity in the Arctic Ocean and in Resolute Passage. Mar Ecol Prog Ser 61:31-40

Rivkin RB, Putt M (1987) Photosynthesis and cell division by Antarctic microalgae: comparison of benthic, planktonic and ice algae. J Phycol 23:223-229

Rivkin RB, Putt M, Alexander SP, Meritt D, Gaudet L (1989) Biomass and production in polar planktonic and sea ice microbial communities: a comparative study. Mar Biol 101: $273-283$

Sakshaug E, Andresen K, Kiefer DA (1989) A steady state description of growth and light absorption in the marine diatom Skeletonema costatum. Limnol Oceanogr 34: 198-205

Schrader GC, Horner R, Smith GF (1982) An improved chamber for in situ measurement of primary productivity by sea ice algae. Can J Fish Aquat Sci 39:522-524

Smith JC, Platt T, Li WKW, Horne EPW, Harrison WG, Subba Rao DV, Irwin BD (1985) Arctic marine photoautotrophic picoplankton. Mar Ecol Prog Ser 20:207-220

Smith REH, Herman AW (1991) Productivity of sea ice algae: In situ vs. incubator methods. J Mar Syst 2:97-110

Smith REH, Herman AW (1992) In situ patterns of intracellu- 
lar photosynthate allocation by sea ice algae in the Canadian High Arctic. Polar Biol 12:545-551

Smith REH, Clement PC, Cota GF, Li WKW (1987) Intracellular photosynthate allocation and the control of Arctic marine ice algal production. J Phycol 23:124-132

Smith REH, Anning J, Clement P, Cota G (1988) Abundance and production of ice algae in Resolute Passage, Canadian A.rctic. Mar Ecol Prog Ser 48:251-263

Sommer U (1994) Planktologie. Springer, Berlin

SooHoo JB, Lizotte MP, Robinson DH, Sullivan CW (1987) AMERIEZ 1986: Photoadaptation of phytoplankton and light limitation of primary production in the ice-edge zone of the Weddell Sea. Antarct J US 22(5):185-187

Spindler M (1990) A comparison of Arctic and Antarctic sea ice and the effects of different properties on sea ice biota. In: Bleil U, Thiede J (eds) Geological history of the polar oceans: Arctic versus Antarctic. Kluwers Academic Publishers, London, p 173-186

Strickland JDH, Parsons TR (1972) A practical handbook of seawater analysis. Bull Fish Res Bd Can 167

Sullivan CW, Palmisano AC, Kottmeier S, Grossi SMcG, Moe R (1985) The influence of light on growth and development of the sea-ice microbial community in McMurdo Sound. In: Siegfried WR, Condy PR, Laws RM (eds) Antarctic nutrient cycles and food webs. Springer, Berlin, p 78-83

Editorial responsibility: Otto Kinne (Editor),

Oldendorf/Luhe, Germany
Syvertsen EE, Kristiansen S (1993) Ice algae during EPOS, leg 1: assemblages, biomass, origin and nutrients. Polar Biol 13:61-65

Thomas DN, Lara RJ, Eicken H, Kattner G, Skoog A (1995) Dissolved organic matter in Arctic multi-year sea ice during winter: major components and relationships to ice characteristics. Polar Biol 15:477-483

Tilzer MM, Dubinski Z (1987) Effects of temperature and day length on the mass balance of Antarctic phytoplankton. Polar Biol 7:351-360

Villafane VE, Helbling EW, Holm-Hansen O, Chalker BE (1995) Acclimatisation of Antarctic natural phytoplankton assemblages when exposed to solar ultraviolet radiation. J Plankton Res 17(12):2295-2306

Weissenberger J (1992) Die Lebensbedingungen in den Solekanälchen des antarktischen Meereises. Ber Polarforsch 111:1-159

Welch HE, Bergmann MA (1989) Seasonal development of ice algae and its prediction from environmental factors near Resolute. NWT, Canada. Can J Fish Aquat Sci 46: 1793-1804

Wheeler PA, Gosselin M, Sherr E, Thibault D, Kirchman DL, Benner R, Whitledge TE (1996) Active cycling of organic carbon in the central Arctic Ocean. Nature 380: $697-699$

Submitted: March 11, 1998; Accepted: October 6, 1998 Proofs received from author(s): February 5, 1999 